\title{
HIGHLY EFFECTIVE BIOSORPTIVE REMOVAL OF CHROMIUM (III) FROM SOIL SAMPLE IN THE VICINITY OF RICE MILL INDUSTRY, CENTRAL INDIA
}

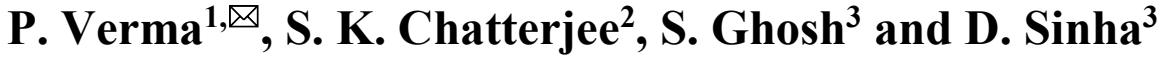 \\ ${ }^{1,3}$ Department of Chemistry, Govt. Nagarjuna Post Graduate College of Science, \\ Raipur-492010, (C.G.) India \\ ${ }^{2}$ Department of Chemistry, Govt. MVPG College, Mahasamund-493445, (C.G.) India \\ ${ }^{\square}$ Corresponding Author: preeti.sweta8@gmail.com
}

\begin{abstract}
Cr heavy metal was observed in a soil sample collected around the rice mill of Bemetara district. The analysis is done by Atomic Absorption Spectrophotometer. The soil sample is collected from 50-4500 m distance. The concentration of Cr (III) is observed $94.330 \mathrm{mg} / \mathrm{kg}$ in $50 \mathrm{~m}$ and $41.780 \mathrm{mg} / \mathrm{kg}$ in $4500 \mathrm{~m}$. Removal of Cr (III) heavy metal is also discussed. The accumulation of various heavy metals in bioadsorbent was confirmed by FTIR. It indicates the involvement of $\mathrm{O}-\mathrm{H}$ (Hydroxyl) and $=\mathrm{CH}$ (alkenes) groups which are metal-binding chelate. Bioadsorbent was used for the removal of toxic heavy metals from industrial effluents. SEM and EDX are also used for the characterization of bioadsorbent. It is noteworthy that even at a maximum exposure time of heavy metal and biomass, the removal of heavy metal becomes higher. The result establishes the efficiency of C. sativum as a very good adsorbent to remove the heavy metals from the soil sample as it is economical for farmers.
\end{abstract}

Keywords: Soil, Heavy Metal, Sample, Atomic Absorption Spectrophotometer, FTIR, SEM, EDX.

RASĀYAN J. Chem., Vol. 14, No.4, 2021

\section{INTRODUCTION}

Soil is the most important ecological factor as it correlates climate region and soil structure. It plays a significant role in the economic development of living beings. ${ }^{1}$ Now a day ecological contamination through heavy metals is a sensitive environmental crisis. ${ }^{2}$ Sources of these heavy metals are agricultural and pharmaceutical activities, power plants, rice mill effluents, domestic effluents as well as electronics etc. ${ }^{3-4}$ In the present decades, these hazardous effluents are produced and released in a very large amount. ${ }^{5}$ Industrialization increases the fast release of toxic elements into the terrestrial ecosystems, thus becoming very dangerous to the atmosphere and human beings. ${ }^{6}$ Heavy metal concentration is also observed in the effluents introduced from rice mill industries. When these effluents are discharged into the environment of soil, the process of relocation, enhancement and renovation of heavy metals generates different ecological pollution. The quality of soil, food crops and water are affected by heavy metal pollutants. Further, the probability of damaging our ecological structure is very high in different ways, from molecules to communities and also human health via the food chain. ${ }^{7}$ Rice is a very important crop of our world ${ }^{8}$ Husk of rice is disposed of near to the rice mill industry. Rice dust obtained from the rice mill industry is always harmful to our environment and contributes to nutrient loss as excess water, this is the factor for reducing the quality of soil because recycling of these soil nutrients is not possible. ${ }^{9}$ In the manufacturing process, rice of parboiled variety is involved. In this process, a cylindrical-shaped steel container is used for steaming paddy. After 5-6 hours of baking period, wastewater collected in the container is discharged and is released in the surrounding open area of the mill. This effluent which contains a high concentration of suspended particles and dissolves organic matter is the major source of soil pollution. After a long time, these effluents cause irreversible changes in the surface soil and water sources, as affected life of humans and plants. ${ }^{10-12}$ Main constituents of rice mill effluent are minerals and dissolved carbohydrates which are acidic with $\mathrm{pH}$ from 4.5 to 5.5. Research in rice mill effluent treatment is very hopeful. ${ }^{13}$ The rice mill effluents contain some physical property like turbidity, coloring, foulsmell and acidic nature with high TDS and COD values that's why treatment of effluents are very

Rasayan J. Chem., 14(4), 2739-2748(2021)

http://dx.doi.org/10.31788/RJC.2021.1446335

This work is licensed under a CC BY 4.0 license. 
important. ${ }^{14}$ Heavy metals have a crucial impact on the atmosphere because of their toxic effect on human beings, plants, animals and deficiency of biodegradability. The rate to accumulate heavy metals from crops and vegetables cultivated in polluted soils is greater than those cultivated in unpolluted soil. Anthropogenic activities are the major sources of polluting our atmosphere using heavy metals. The concentration of the toxic metals in various foods depends on the composition of soil, water and nutrient imbalance, with tolerability, selectivity and assimilation ability of metal. Heavy metals are very injurious because of their possible accumulation in various parts of the human body. A low concentration of heavy metal is also very harmful to the human body because of its non-biodegradable property and continual in nature. ${ }^{15-17}$

Chromium is identified as a heavy metal that can spoil plants and animals. Cell membranes of plants are damaged because of lipid peroxidation caused by the induction of oxidative stress. A higher concentration of chromium can disturb the ultra structure of the chloroplast there by disquieting the process of photosynthesis. As seed germination is affected by $\mathrm{Cr} .{ }^{18}$ Compact germination of the seeds beneath $\mathrm{Cr}$ stress depressed $\mathrm{Cr}$ amylases actions and the transport activity of sugars. Reduces in the growth of roots is a recognized effect caused by heavy metals in crops and trees. ${ }^{19}$ According to Prasad. ${ }^{20}$ The toxicity of metals in primordial (new root) in the plant of Salix viminalis is observed that the concentration of Cd is very high and $\mathrm{Pb}$ concentration is observed very low and $\mathrm{Cr}$ heavy metal affect the root length compared to other heavy metals. Cr stresses also affects the process of photosynthesis as the action of photophosphorylation, $\mathrm{CO}_{2}$ fixation, enzyme activities and electron transport. ${ }^{21}$

There are some agriculture byproducts that are productive and progressive adsorbents like peat coconut shells, nutshells, bone, wood which changed into activated carbons and also biomass like Rhizopus aehizus and Aspergillus tereus. Still, these materials are efficient adsorbents that can remove heavy metals from industrial wastewater. ${ }^{22}$ Phyto-remediation methods are eco-friendly and economical that are based on the plants available in large quantities. ${ }^{23}$ In this research, we just focused on domestic heavy metal removal plants by phytoremediation technique. Coriandrum sativum (C. sativum) is usually known as "Coriander," which is a small annual plant and cultivated before $1550 \mathrm{BC}$. It is particularly the oldest spice crop grown all over the world. The plant belongs to the family Apiaceae that contains 300 genera and about 3000 species. ${ }^{24}$ C. sativum is normally known as Dhaniya, which is commonly found in India, Bangladesh, Itlay, China, Netherlands, and Central - Eastern Europe. It is an extremely recognized ayurvedic small size medicinal plant which has antioxidant, antimutagenic, sedative-hypnotic, anticonvulsant, anti-microbial and anthelmintic properties. Biochemical and pharmaceutical studies of various parts of $C$. sativum have been conducted. This study supports its capability as a medicinal plant. In addition, more studies should be done to analyze the advantages of this herb. ${ }^{25-27}$ C. sativum excreted heavy metals from patient's urine and also increased the efficiency of antibiotics. ${ }^{28} \mathrm{C}$. sativum seed is also studied, and the presence of polyphenols (galic acid, rutin, ferulic acid, chlorogenic acid and caffeic acid derivatives), $\beta$ - carotenoids and flavonoids (quercetin and isoquercetin). ${ }^{29}$ Every part of the plant are suitable for eating, but dried seeds and fresh leaves are the very important parts used in food preparation. In India, coriander is used in urinary, digestive and respiratory disorders because it has carminative diaphoretic, stimulant and diuretic activity. C. sativum plant is also used in the detoxification of heavy metals. $^{30}$

\section{Material and Methods}

\section{EXPERIMENTAL}

The crop fielding region of Bemetara District of Central India was selected for the soil sample collection. The area of research is Shri Bhadrakali Rice Mill. This rice mill is located about $10 \mathrm{~km}$ away from Bemetara district, India and is in $81.2849^{\circ} \mathrm{E}$ longitude and $21.1917^{\circ} \mathrm{W}$ latitude in Chhattisgarh, India (Fig.-1). Usually, black soil is found in this area. The local name of black soil is Kanhar Mati.

Ten soil samples (approx. $200 \mathrm{gm}$ ) were collected in summer season (May, 2019) from the upper layer 0$10 \mathrm{~cm}$ using stainless steel auger for coning and quartering, animal burrowing is completely avoided. Then collected soil samples were transferred in the air-tight polythene bags and were stored at $4^{\circ} \mathrm{C}$ till further processing. After removal of stones and twigs soil samples were air-dried and homogenized with 2 $\mathrm{mm}$ sieve. ${ }^{31}$ One gm of dried sample was placed in a Beaker of $250 \mathrm{ml}$ volume separately and added aquaregia $(15 \mathrm{ml})$. Then the mixture was digested at $70^{\circ} \mathrm{C}$ of temperature until the solution turned 
transparent. The solution was filtered using Whatman filter paper of no. 42 and diluted to $50 \mathrm{ml}$ of deionized water to $50 \mathrm{ml}$ volumetric flask and this filtrate were ready to evaluate the concentration of $\mathrm{Cr}$ (III) heavy metals by use of an atomic absorption spectrophotometer.

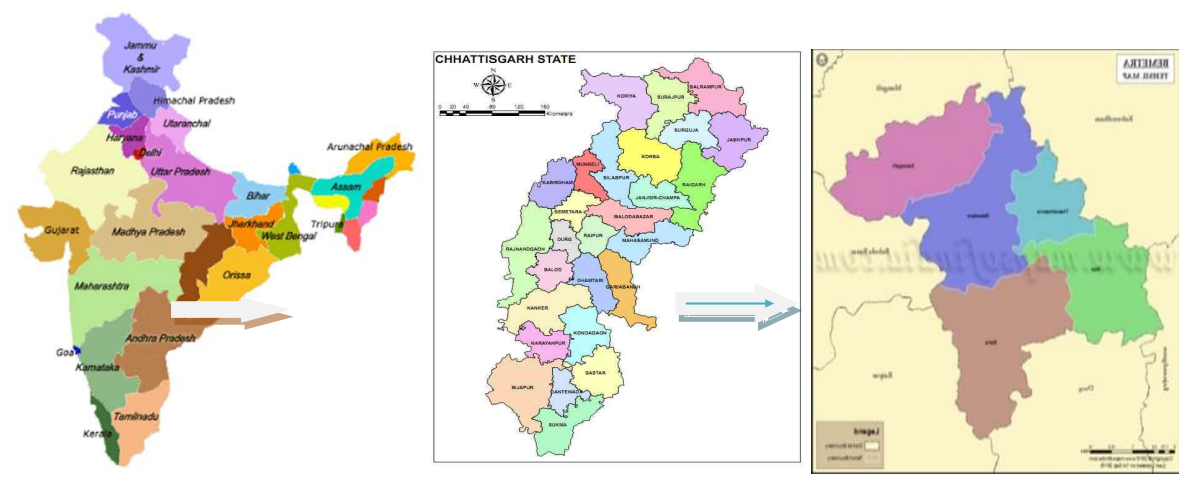

Fig.-1: Map of India, Chhattisgarh and Bemetara District

\section{Batch Adsorption Experiments}

Removal of $\mathrm{Cr}$ (III) heavy metal from rice mill effluents was carried out by Batch experiment. The experiment was conducted for 10, 20, 30, 40, 50, 60, 70 and $80 \mathrm{~min}$. In the batch adsorption experiment, $100 \mathrm{ml}$ of industrial effluent was transferred in $250 \mathrm{ml}$ of plastic bottles and $2.0 \mathrm{gm}$ of biomass was added to each bottle. After the filtration technique concentration of $\mathrm{Cr}$ (III) is determined by ICPMS.

Effect of $\mathrm{pH}$ on biosorption: $\mathrm{pH}$ is essential for the adsorption of $\mathrm{Cr}$ (III) heavy metal. In the current work, removal of different heavy metals was observed at various $\mathrm{pH}$ ranges as 1.0-7.0, at a concentration of $180 \mathrm{mg} / \mathrm{L}$, biosorbent dosage $2 \mathrm{gm} / 100 \mathrm{ml}$ at a fixed contact time of $50 \mathrm{~min}$.

Contact time Effective removal of heavy metal is completed very strongly by contact time. This experiment was conducted at $\mathrm{pH} 6$ and the concentration of metal ion was identified at $180 \mathrm{mg} / \mathrm{L}$ with the same contact time of $50 \mathrm{~min}$.

\section{Dosage of Sorbents}

The percentage removal of various heavy metals at different biosorbent dosages was observed. This experiment was analyzed at an initial concentration of $180 \mathrm{mg} / \mathrm{L}$ and at $\mathrm{pH} 6$. No significant change was observed after $2 \mathrm{gm} / 100 \mathrm{ml}$. That's why $2 \mathrm{gm} / 100 \mathrm{ml}$ was selected as the most favorable biosorbent dose.

\section{Initial Concentration}

Variation in heavy metal removal is observed in this experiment. For different heavy metals, the concentration was varied from 100 to $300 \mathrm{mg} / \mathrm{L}$.

\section{Phytoremediation Technique}

The phytoremediation technique has become very effective in the last few years, which is a very reactive technology related to the recovery of soil. The phytoremediation technique uses green plants for the removal of pollutants from the contaminated area.

Application of diverse metabolites present with the concentrations of millimolar, particularly in amino acids, for example, proline, histidine and peptides like glutathione (GSH), shows defense mechanism across heavy metal action. Antioxidants with low molecular weight as glutathione remove the toxic property of free radicals. Many compounds with loaded - SH groups are non-proteineous; they also have the binding capacity with a metal ion to form non-hazardous compounds between the metals. ${ }^{32-34}$

\section{Soil}

Plants of Coriander (Coriandrum Sativum) were cultivated in the selected plastic pots with $19 \mathrm{~cm}$ diameter as well as a height of $15 \mathrm{~cm}$ for the experiment. Pots were packed from the base to avoid leakage of heavy metals from the soil. Every pot was filled with $2 \mathrm{~kg}$ black soil of Bemetara (C.G.) district. The 
$\mathrm{pH}$ of the soil was observed 5.2 in $1 \mathrm{M}$ of $\mathrm{KCl}$ and 6.0 in an aqueous system. Thoroughly mixed soil with $\mathrm{Cr}$ heavy metal and mixture was left for 1 month before crop growing to equilibrate.

\section{Plant Material}

The plant of C. Sativum was grown for 60 days. Each ten pots were cultivated for five plants. 50 plants were used in each experiment. Shoots in different lengths were obtained (according to heavy metal). Mature stems and leaves were taken for further analysis. For the recent biochemical experiment, plant material was mixed for each pot and five replicates were selected for the experiment. After 2-month, the length of the apical leaf and basal stem was measured as well as biomass of the entire aerial part was also estimated. Twenty plants were taken in each experimental group (each pot included two plants).

\section{Identification of Heavy Metal Concentration in Plant and Soil Sample}

Heavy metal concentration was observed in particular soil, leaves and shoots of plants. Metal content in soil was estimated. $2 \mathrm{M}$ of $\mathrm{HNO}_{3}$ was used for the extraction process of $1-\mathrm{mm}$ sieved air-dried soil samples. $10 \mathrm{gm}$ of soil sample was dissolved in $100 \mathrm{ml}$ of $\mathrm{HNO}_{3}(2 \mathrm{M})$ shaked thoroughly for $60 \mathrm{~min}$ to obtain the $\mathrm{HNO}_{3}$-extraction. Finally, flame absorption spectrometry (iCE 3000 AA05120906 v1.30) was used to measure the heavy metal content from the filtered extracts. For determination of heavy metal concentrations in plant leave and stems, first, we washed plant material in tap than distilled water. Then plant material was dried at $105^{\circ} \mathrm{C} .0 .25$ gm of dried plant material was dissolved in $5 \mathrm{ml}$ of $\mathrm{HNO}_{3}$ than digested at $110^{\circ} \mathrm{C}$ of temperature and followed by dilution with $10 \mathrm{ml}$ deionized water. Subsequently, $\mathrm{Cr}$ (III) heavy metal was observed using flame absorption spectrometry (iCE 3000 AA05120906 v1.30). Reference material with similar quantities of the sample was used. ${ }^{35-38}$

\section{RESULTS AND DISCUSSION}

In the laboratory, some physicochemical parameters were analyzed using the standard method. The physical and chemical properties of rice mill effluents are shown in Table-1.

Table-1: Physico-chemical Property of Cr (III) Heavy Metal

\begin{tabular}{c|c|c}
\hline Physico-chemical Parameter & Sample 1 & Sample 2 \\
\hline Appearance & Turbid & Turbid \\
\hline Odor & Fowl & Fowl \\
\hline pH & 7.1 & 6.8 \\
\hline Suspended solids $(\mathrm{mg} / \mathrm{L})$ & 267 & 271 \\
\hline BOD $(\mathrm{mg} / \mathrm{L})$ & 410 & 586 \\
\hline COD $(\mathrm{mg} / \mathrm{L})$ & 1780 & 2450 \\
\hline TDS $(\mathrm{mg} / \mathrm{L})$ & 2430 & 3248 \\
\hline Conductivity $\left(\mathrm{micro} \mathrm{ohm}^{-1}\right.$ & 3651 & 3654 \\
$\left.\mathrm{~cm}^{-1}\right)$ & & \\
\hline Chloride $(\mathrm{mg} / \mathrm{L})_{\text {Sulphate }(\mathrm{kg} / \mathrm{h})}$ & 654 & 1753 \\
\hline Phosphorous $(\mathrm{kg} / \mathrm{h})$ & 29.7 & 23.00 \\
\hline Fluoride $(\mathrm{mg} / \mathrm{L})$ & 8.83 & 11.74 \\
\hline Sodium $(\mathrm{mg} / \mathrm{L})$ & 0.92 & 0.81 \\
\hline Potassium $(\mathrm{kg} / \mathrm{h})$ & 531 & 327 \\
\hline Total Hardness $(\mathrm{mg} / \mathrm{L})$ & 230.80 & 189.32 \\
\hline Ca Hardness $(\mathrm{mg} / \mathrm{L})$ & 471 & 895 \\
\hline Mg Hardness $(\mathrm{mg} / \mathrm{L})$ & 562 & 814 \\
\hline Total $($ KJ) Nitrogen $(\mathrm{kg} / \mathrm{h})$ & 63 & 94 \\
\hline
\end{tabular}

Commonly metals are found in various types of ecosystems. ${ }^{39}$ Naturally, heavy metals are obtained in soil, but the activity of human beings increases its concentrations so that our soil becomes more polluted. For organism's healthy growth, some trace elements are essential, but their high concentrations can be toxic. 


$$
\mathrm{Zn}>\mathrm{Pb}>\mathrm{Mn}>\mathrm{Cu}>\mathrm{Cr}>\mathrm{Cd}>\mathrm{Ni}>\mathrm{Co}
$$

Table-2: Heavy Metal Concentration of Study Area

\begin{tabular}{c|c|c|c|c|c|c|c|c|c|c}
\hline Distance in m & 50 & 500 & 1000 & 1500 & 2000 & 2500 & 3000 & 3500 & 4000 & 4500 \\
\hline $\begin{array}{c}\text { Concentration } \\
\text { of Cr (III) } \\
\text { heavy metal }\end{array}$ & 94.330 & 94.050 & 93.840 & 83.420 & 77.390 & 69.450 & 51.940 & 51.460 & 41.580 & 41.780 \\
\hline
\end{tabular}

Table-3: Summary of the Soil Properties of the Study Area

\begin{tabular}{c|c|c|c}
\hline \multirow{2}{*}{$\begin{array}{c}\text { Cr (III) } \\
\text { element }\end{array}$} & \multicolumn{3}{|c}{ The concentration of heavy metal in $\mathrm{mg} / \mathrm{kg}$} \\
\cline { 2 - 4 } & Min & Max & Mean \\
\cline { 2 - 4 } & 41.580 & 94.330 & 69.924 \\
\hline
\end{tabular}

The concentration of Cr (III) heavy metal is shown in Table 2 and Fig.-2 around the vicinity of the rice mill industry with varying distances at 50 to $4500 \mathrm{~m}$. In maximum cases, the concentration of heavy metal is high near about rice mill industry $(50 \mathrm{~m})$. As we increase the distance from industry, the concentration of $\mathrm{Cr}$ (III) heavy metal also increases. The summary of Table 2 is shown in Table 3.

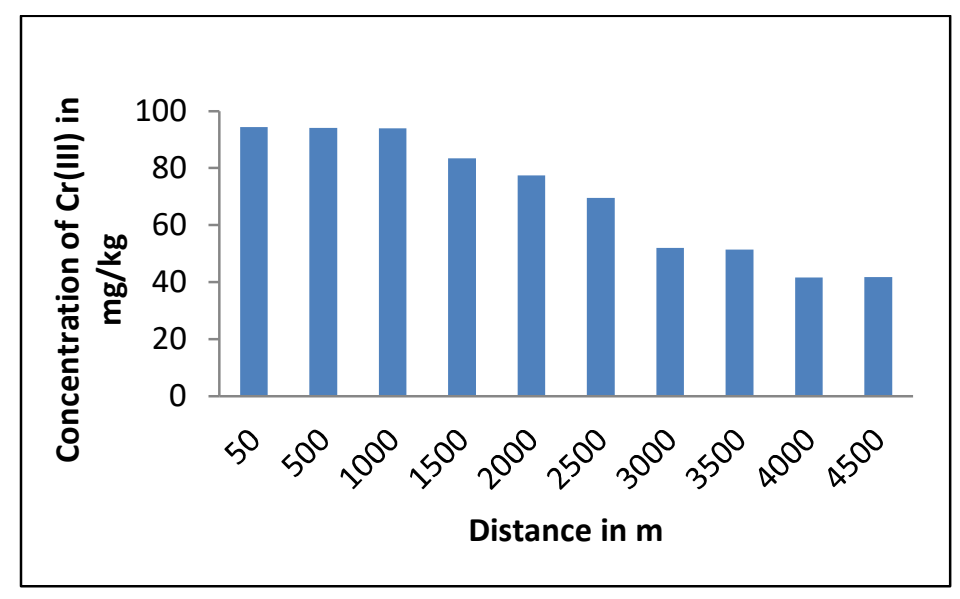

Fig.-2: Concentration of $\mathrm{Cr}$ (III) heavy metal

Significant concentration showed by other toxic metals like $\mathrm{Cr}$ and $\mathrm{Mn}$ in surface soil. Speciation of the metal is responsible for the mobility of chromium in surface soil, which is caused by redox potential and soil $\mathrm{pH}$. In soil, $\mathrm{Cr}$ is present in Chromium (III). ${ }^{40}$ Organic matter, acidity, wetness, biological activities affect the mobility of $\mathrm{Mn}$ in soil. Redox potential and $\mathrm{pH}$ of soil also control the solubility of manganese in the soil. At a soil $\mathrm{pH}$ of more than 6 , manganese binds with oxides and silicates and organic matter, thus its solubility decreases. Availability and solubility of $\mathrm{Mn}$ decreases at high concentration of $\mathrm{pH} .{ }^{41-42}$

\section{FTIR Spectra of Biomass}

Observation of functional group is carried by FTIR method for adsorption process. Thus, Fig.-3 and 4 indicate variation in functional groups of the FTIR spectrum of given biomass before and after adsorption. FTIR spectra of the biomass show the typical band of bromo compound at $690.89 \mathrm{~cm}^{-1}$ combined with C$\mathrm{Br}$ stretching vibration. Aliphatic chloro compound shows at $775.56 \mathrm{~cm}^{-1}$ correlate with $\mathrm{C}-\mathrm{Cl}$ stretch. The intense absorption peak at $1006.26 \mathrm{~cm}^{-1}$ indicates the stretching vibration of aliphatic fluoro compound with C-F stretch. Primary amine compound observes at $1635.10 \mathrm{~cm}^{-1}$ with N-H stretch. The IR band in the range of $3608.24 \mathrm{~cm}^{-1}$ indicates the tertiary alcohol with $\mathrm{O}-\mathrm{H}$ stretching vibration.

After adsorption halogen peak shows a little change from 630.83 to $1029.43 \mathrm{~cm}^{-1}$. Before and after the adsorption functional groups and their wavelength peaks are given in Table- 4 . 
RASĀYAN J. Chem.

Vol. 14 | No. 4 |2739-2748| October- December | 2021

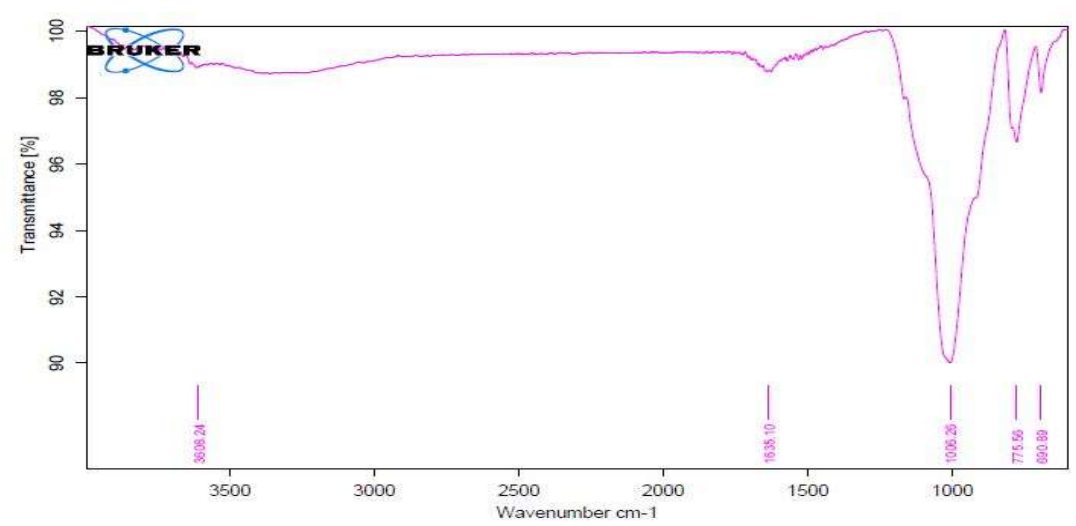

Fig.-3: FTIR Spectra of Fresh Biomass

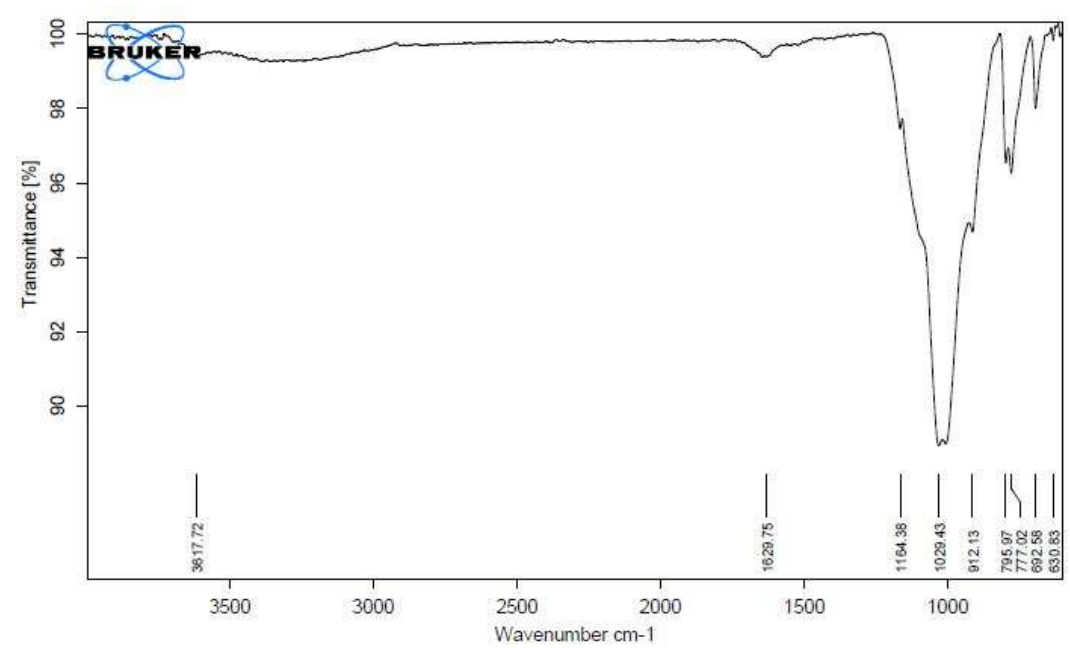

Fig.-4: FTIR Spectra of Cr (III) Loaded Biomass

Table-4: FTIR Data of Fresh and Loaded Biomass (IR absorption band and their related functional groups)

\begin{tabular}{c|c|c|c|c|c}
\hline S. No. & $\begin{array}{c}\text { Native biomass } \\
\left(\mathrm{cm}^{-1}\right)\end{array}$ & $\begin{array}{c}\text { Metal loaded } \\
\text { biomass }\left(\mathrm{cm}^{-1}\right)\end{array}$ & $\begin{array}{c}\text { Change in peak behaviors } \\
\text { on loaded biomass }\end{array}$ & $\begin{array}{c}\text { IR peak range } \\
\left(\mathrm{cm}^{-1}\right)\end{array}$ & Functional group \\
\hline 1 & 3608.24 & 3617.72 & Shift & $3700-3584$ & $\begin{array}{c}\text { OH stretching } \\
\text { (Alcohol) }\end{array}$ \\
\hline 2 & 1635.10 & 1629.75 & Shift & $1662-1626$ & $\begin{array}{c}\text { C=C } \\
\text { Stretching }\end{array}$ \\
\hline 3 & Absent & 164.38 & Disappear & $210-1163$ & Ester \\
\hline 4 & 1006.26 & 1029.43 & Shift & $1000-1400$ & C-F stretch band \\
\hline 5 & Absent & 912.13 & Disappear & $950-910$ & O-H band \\
\hline 6 & 775.56 & 795.97 & Shift & $600-800$ & $\begin{array}{c}\text { C-Cl stretch } \\
\text { band }\end{array}$ \\
\hline 7 & Absent & 772.02 & Disappear & $675-1000$ & $\begin{array}{c}=\text { C-H } \\
\text { bending }\end{array}$ \\
\hline 8 & 690.89 & 692.58 & Shift & $850-550$ & $\begin{array}{c}\text { C-Cl stretch } \\
\text { band }\end{array}$ \\
\hline 9 & Absent & 630.83 & Disappear & $690-515$ & $\begin{array}{c}\text { C-Br Stretch } \\
\text { Band }\end{array}$ \\
\hline
\end{tabular}

SEM and EDX analysis

SEM was used for characterization of the bioadsorbent and EDX determined the chemical composition. Fig.-5 shows the SEM picture of C. Sativum biomass at $\times 1000$ magnification identified no metal 
adsorption. Another picture of SEM in Fig.-6 is clearly evident to prove the covered surface of the biomass with a large number of pores and rough grooves, which is responsible for the adsorption of $\mathrm{Cr}$ (III). While before adsorption, the EDX picture of $\mathrm{C}$. Sativum bioadsorbent the $\mathrm{Ca}, \mathrm{C}, \mathrm{Mg}, \mathrm{K}, \mathrm{O}, \mathrm{Cl}$ and $\mathrm{Si}$ atom were identified other than after the adsorption of metal $\mathrm{Cr}$ (III) was present with the biomass that is shown in Fig.-5. The percentage composition of fresh and $\mathrm{Cr}$ (III) loaded biomass is shown in Table-5.
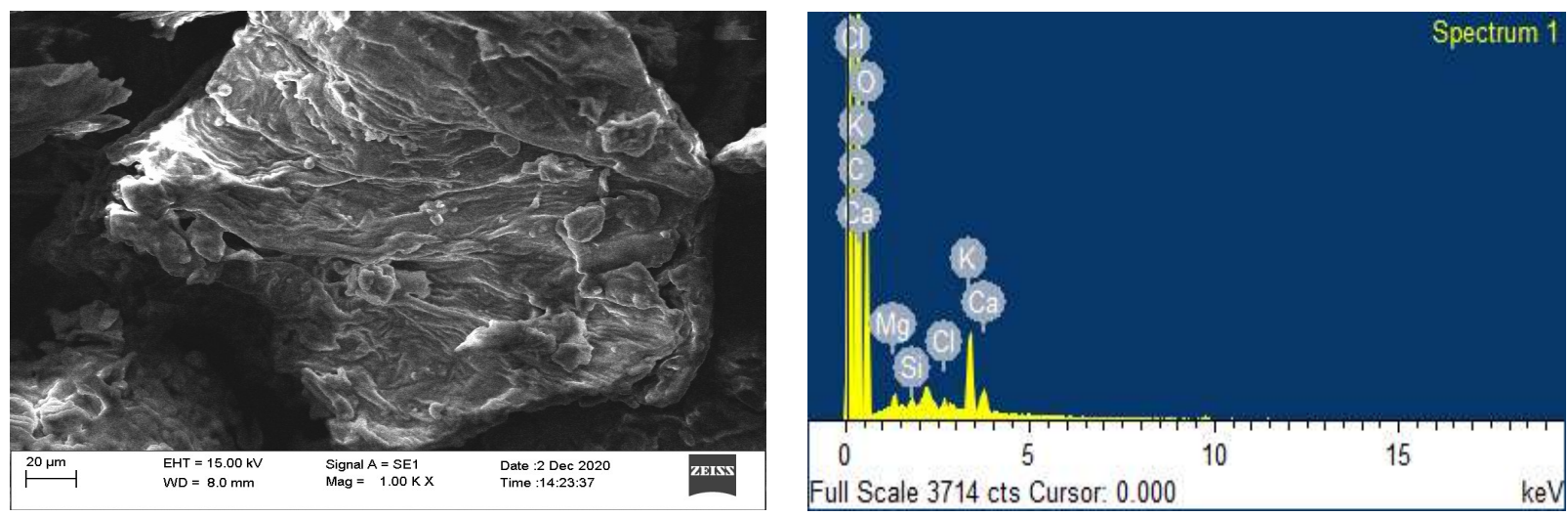

Fig.-5: SEM Image and EDX Spectra of Fresh Biomass
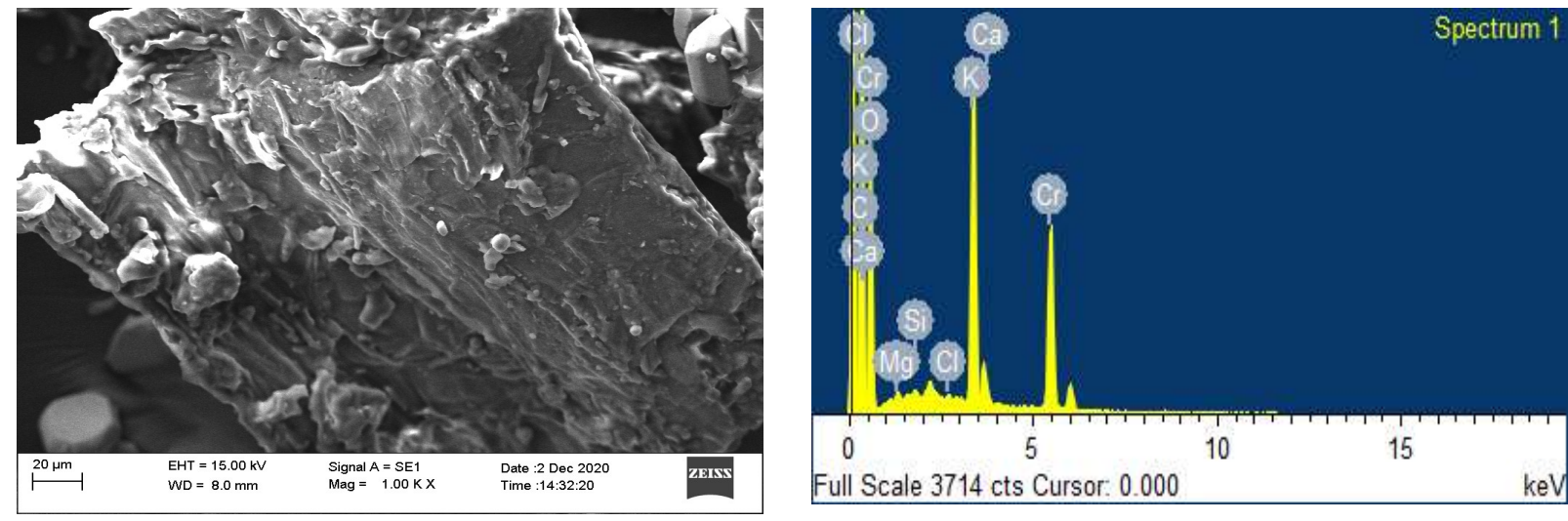

Fig.-6: SEM Image and EDX Spectra of Loaded Biomass

Table-5: Present Compound in Native and Loaded Bioadsorbent (C. Sativum) from EDX Study

\begin{tabular}{c|c|c|c}
\hline Compound & Oxygen $(\mathrm{O}) \%$ & Carbon $(\mathrm{C}) \%$ & Chromium [Cr (III)] \% \\
\hline (Native) & 63.57 & 31.94 & - \\
\hline Cr (III) loaded & 61.78 & 17.69 & 21.85 \\
\hline
\end{tabular}

\section{Batch Adsorption Experiments}

Batch adsorption experiment is shown in Fig.-7. The graph is plotted between percentage removal of $\mathrm{Cr}$ (III) heavy metal and time (min). Samples were filtered and the filtrate was used to determine the final concentration of $\mathrm{Cr}$ (III) heavy metals by ICPMS.

\section{Effect of pH}

It was found that the removal percentage of given eight heavy metals increased at $\mathrm{pH}$ 6.0. On increasing $\mathrm{pH}$ it decreases. After $\mathrm{pH} 7.0$, precipitations take place. So that $\mathrm{pH} 6.0$ was observed as a favorable $\mathrm{pH}$.

\section{Contact Time}

Contact time is responsible for the effective removal of $\mathrm{Cr}$ (III) heavy metals. Thus, the experiment was held at $\mathrm{pH} 6.0$ and $180 \mathrm{mg} / \mathrm{L}$ metal ion concentrations with different contact times. The percentage 
removal of given $\mathrm{Cr}$ (III) heavy metal increases from 70 to $100 \%$ when we increase the contact time from 20 to $50 \mathrm{~min}$. In the beginning, adsorption rate is very high because many active sites are available for the process of adsorption. The maximum percentage removal of $\mathrm{Cr}$ (III) heavy metal was observed within the initial $50 \mathrm{~min}$. Further increase in contact time was not beneficial. So that, the contact time was set as 50 min.

\section{Adsorbent Dosage}

Biosorbent dosage affects the percentage removal of $\mathrm{Cr}$ (III) heavy metal, which was identified at a different dosage of adsorbent between the ranges of (1-8 gm/L) $\mathrm{Cr}$ (III) heavy metal concentration was found $(180 \mathrm{mg} / \mathrm{L})$ with $\mathrm{pH}$ 6.0. No change was observed in the removal percentage of $\mathrm{Cr}$ (III) heavy metal with increased dosage of biosorbent after $2 \mathrm{gm} / 100 \mathrm{ml}$. Therefore, $2 \mathrm{gm} / 100 \mathrm{ml}$ concentration was selected as the most favorable dosage of biosorbent.

\section{Initial Concentration}

Given experiment shows in the variation of Cr (III) heavy metal concentration from 100 to $500 \mathrm{mg} / \mathrm{L}$ with the biosorbent dose $2 \mathrm{gm} / 100 \mathrm{ml}, \mathrm{pH} 6.0$ and standing time $50 \mathrm{~min}$. In batch adsorption mode it was identified that the removal percentage of Cr (III) heavy metal decreases from 95 to $100 \%$, at the time when metal ion concentration increased from 100 to $500 \mathrm{mg} / \mathrm{L}$.

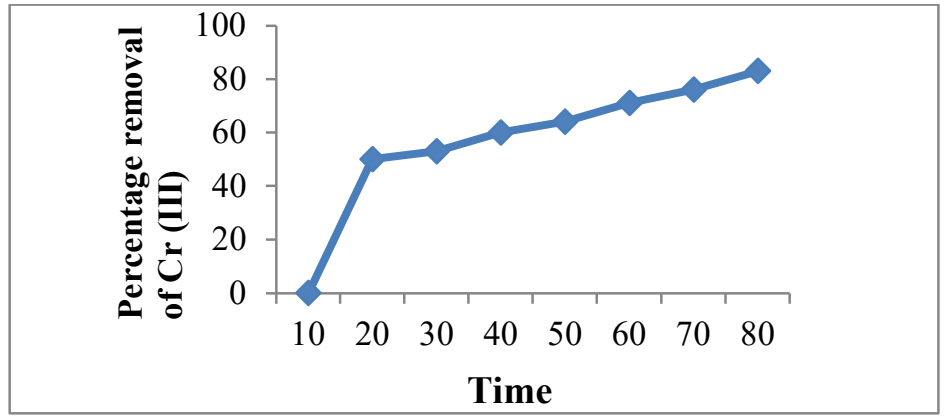

Fig.-7: Removal of Cr (III) Heavy Metal

\section{CONCLUSION}

The above results were obtained from the soil sample collected from the rice mill industry of Bemetara District of Chhattisgarh state. The result shows that the concentration of $\mathrm{Cr}$ (III) heavy metal is high at 50 $\mathrm{m}$ distance from the rice mill industry. This analysis shows the broad contamination of heavy metals around the rice mill industry. This heavy metal is the most polluted heavy metal on the study site.

Closer monitoring is necessary for the study area. The observed pollutant was $\mathrm{Cr}$ (III). Its concentration is high in the soil of the study area. Traffic emission is also responsible for increasing heavy metal concentration in the vicinity of the rice mill industry. Further study is important to examine the effect of heavy metals on rice production. Over time it is required to work to get any changes in soil quality of the industrial area.

Leaves of C. Sativum plant reflect pollutants of the soil. It is found that Cr (III) heavy metal was toxic to C. Sativum and responsible for inhibiting the growth of the plant. The above experiment shows the considerable increase in Cr (III) heavy metal detected in plants, that's why the specific plants are forced to supply their energies to defense against anti-oxidative. Therefore, it is essential to remove heavy metals from the farming area to increase its mobility in soil by using plant with a high accumulating property like C. Sativum, which are comparatively cheap, convenient and economically useful for formers. Percentage removal of $\mathrm{Cr}$ (III) heavy metal using C. Sativum bioadsorbent is $86 \%$ by phytoremediation technique.

\section{ACKNOWLEDGEMENT}

The authors are grateful to the authorities of Government Nagarjuna Post Graduate College of Science, Raipur (India) and Department of Soil Science Indira Gandhi Krishi Vishwavidyalay, Raipur (India), for providing necessary laboratory facilities. 
RASĀYAN J. Chem.

Vol. 14 | No. 4 |2739-2748| October- December | 2021

\section{REFERENCES}

1. R. Kaur, M. Bansal, S. Sharma and S. Tallapragada, Rasayan Journal of Chemistry, 12, 421(2019), https://doi.org/10.31788/RJC.2019.1225160

2. K. M. Satova, S. M. Zhumadina, S. B. Abilova, N. B. Mapitov and A. K. Jaxylykova, Rasayan Journal of Chemistry, 13, 1627(2020), https://doi.org/10.31788/RJC.2020.1335672

3. N. C. Joshi, V. Bahuguna, Rasayan Journal of Chemistry, 11, 142(2018), https://doi.org/10.7324/RJC.2018.1112008

4. Q. H. Tran, N. T. Nguyen, Rasayan Journal of Chemistry, 13, 1792(2020), https://doi.org/10.31788/RJC.2020.1335360

5. J. Pachiyappan, N. Gnanasundaram, Rasayan Journal of Chemistry, 13, 2027(2020), https://doi.org/10.31788/RJC.2020.1335827

6. L. Adathodi, R. Murugadoss J., K. Gaddam, Rasayan Journal of chemistry, 11, 1204(2018), https://doi.org/10.31788/RJC.2018.1134009

7. L. Chuanzhang, X. Wang, H. Huang, L. Wang, F. Wei, C. Zhang and Q. Rong, Human Ecological Risk Assessment: An International Journal, 31, 1(2020)

8. S. Ghasemi and R. M. Gholami, Journal of Health Sciences, 7, 234(2015), https://doi.org/10.5812/jihs.23498

9. R. Hauser, S. Elreedy, J. A. Hoppin and D. C. Christiani, Occupational and Environmental Medicine, 52,353(1995), http://dx.doi.org/10.1136/oem.52.5.353

10. C. N. Mbah, Nigerian Journal of Soil Science, 16, 104(2006)

11. S. S. Nagane, S. S. Kuhire, U. A. Jadhav, S. A. Dhanmane and P. P. Wadgaonkar, Journal of Polymer Science Part A: Polymer Chemistry, 57(5), 630(2019), https://doi.org/10.1002/pola.29303

12. M. Behera, P. S. Jana, T. T. More and M. M. Ghangrekar, Bioelectrochemistry, 79, 228(2010), https://doi.org/10.1016/j.bioelechem.2010.06.002

13. V. B. Patil, M. Medhi, N. S. Bhairamadgi, P.P. Wadgaonkar and N. N. Maldar, Materials Science and Engineering: B, 168(1-3), 186(2010), https://doi.org/10.1016/j.mseb.2009.12.036

14. R. Proshad, T. Kormoker, M. D. S. Islam and K. Chandra, Human Ecological Risk Assessment, 3, 1(2019)

15. J. R. Peralta, J. L. G. Torresdey, K. J. Tiemann, E. Gomez, S. Arteaga and E. Rascon, Environmental Contamination and Toxicology, 66, 727(2001)

16. S. R. Tang, B. M. Wilke, R. R. Brooks and S. R. Tang, Communication in Soil Science and Plant Analysis, 32, 895(2001)

17. M. N. V. Prasad, M. Greger, T. Landberg, International Journal of Phytoremediation, 3, 289(2001)

18. H. Clijsters, F. V. Assche, Photosynthesis Research, 7, 31(1985)

19. P. Kamble, R. H. Landge, A. N. Lande and V. P. Dhulap, Rasayan Journal of Chemistry, 12,1864(2019), https://doi.org/10.31788/RJC.2019.1245324

20. G. Sreelatha, P. Srineetha, M.V.S.M. Reddy and K. Ravindhranath, Rasayan Journal of Chemistry, 13, 2230(2020)

21. J. Asgarpanah, N. Kazemivash, African Journal of Pharmacy and Pharmacology, 6,2340(2012)

22. N. Gaur, A. Kukreja, M. Yadav, A. Tiwari, Biotechnology, 7, 196(2017)

23. S. E. Masry, H. S. Ali, N. M. E. Sheikh and S. M. Awad, International Journal of Research Studies in Bioscience, 4, 36(2016)

24. E. Yibru, M. K. C. Menon, Y. Belayneh, D. Seifu, International Journal of Health Science Research, 5, 166(2015)

25. N. Pathak, S. B. Kasture, N. M. Bhatt, International Journal of Pharmaceutical Science and Research, 9, 159(2011)

26. S. P. Ghosh, M. S. Kumar, Human Ecological Risk Assessment: An International Journal, 6, 1(2019)

27. Z. Wei, J. Woonchung and D. Chen, Microchemical Journal, 74, 207(2003)

28. S. S. Sharma, K. J. Dietz, Journal of Experimental Botany, 60, 468(2007)

29. L. Bouwman, J. Bloem, P. Römkens and G. Boon, Journal of Experimental Botany, 57, 711(2006)

30. R. L. Sun, Q. Z. Zhou, F. H. Sun and C. X. Jin, Minerva Biotechnology, 13, 19(2001)

BIOSORPTIVE REMOVAL OF CHROMIUM (III) FROM SOIL 


\section{RASĀYAN $J$. Chem.}

Vol. 14 | No. 4 |2739-2748| October- December | 2021

31. R. K. Sharma, M. Agrawal and F. Marshall, Ecotoxicology and Environmental Safety, 66,258(2007), https://doi.org/10.1016/j.ecoenv.2005.11.007

32. J. L. Martinez, Environmental Pollution, 157, 2893(2009), https://doi.org/10.1016/j.envpol.2009.05.051

33. M. Robson, Ecotoxicology and Environmental Safety, 56, 1049(2003)

34. B. K. Sharma, Environmental Chemistry, 77, 333(1993)

35. J. C. Akan, F. I. Abdulrahman, G. A. Dimari and A. O. Ogugbuaja, European Journal of Scientific Research, 29, 122(2008)

36. K. M. Banat, F. M. Howari and A. A. Al-Hamad, Environmental Research, 97, 258(2005), https://doi.org/10.1016/j.envres.2004.07.002

37. S. K. Guttikunda, P. Jawahar, Atmospheric Environment, 62, 551(2012), https://doi.org/10.1016/j.atmosenv.2012.08.074

38. R. C. Oginyi, O. S. Mbam, C. O. Abojei, O. N. James, World Applied Science Journal, 35, 1133(2017)

39. C. Koteswaramma, Journal of Evolution of Medical and Dental Science, 6, 4297(2017)

40. S. R. Asati, International Journal of Life Sciences Biotechnology and PharmaceuticalResearch,2, 264(2013)

41. K. Kumar, M. R. Gidde, International Journal of Science and Technology, 2, 195(2014)

42. A. Pradhan, S. K. Sahu and A. K. Dash, International Journal of Scientific and Engineering Research, 4, 2706(2013).

[RJC-6335/2020] 